\title{
Distance Education in Library and Information Science Discipline: The Valdosta State University Case
}

\author{
Wallace Koehler and Vera Blair \\ Valdosta State University, Valdosta, Georgia, United States
}

wkoehler@valdosta.edu verablair@yahoo.com

\begin{abstract}
The library and information science discipline in the United States has thoroughly embraced distance education to deliver its courses and other curricular offerings. Courses ha ve been or are offered through a variety of mechanisms, some with deep historical roots, others are dependent upon new and emerging Internet technologies. Different distance education methods offer different opportunities but also diffe rent problems. This paper discusses the approach taken at one university - asynchronous Web course delivery - and the lessons we have learned from those experiences. Given our circumstances and opportunities, we have at times adopted alternatives to technological solutions, including hybrid courses and cross-listing of courses at sister institutions to meet student needs.
\end{abstract}

Keywords: distance learning, asynchronous, Internet, distance education, DE, technology.

\section{Introduction}

There has been a great deal of interest shown by educators in recent years in various aspects and the fields of library and information sciences are no exception (see e.g. Sloan and Stoerger 2002). This paper addresses a specific case study, an application of distance education in a start-up graduate program in library and information science.

Distance education is, of course, not a new concept. Many colleges and universities offered instruction through correspondence programs. There are several different models that have been used to provide distance education. These can be divided by temporal and technological variables. The first distance education efforts can be classed as "correspondence courses." Correspondence courses typically are offered in an open-ended although not limitless time span. That is to say, correspondence students would enroll in a course and they would work at their own pace until the instruction block was completed. Less frequently, correspondence courses are offered for a fixed term; and when they are it is typically for a semester or other academic year divisions.

Course-ware has been developed and commercialized to provide a supportive electronic environment for course management. In the United States, course-ware vendors include BlackBoard, e-College, and WebCT, among others. Often individual departments or universities and sometimes - as it is in our case - the state university system of more than thirty colleges and universities will contract with a single vendor to provide course-ware and support.

Material published as part of these proceedings, either on-line or in print, is copyrighted by Informing Science. Permission to make digital or paper copy of part or all of these works for personal or classroom use is granted without fee provided that the copies are not made or distributed for profit or commercial advantage AND that copies 1) bear this notice in full and 2) give the full citation on the first page. It is permissible to abstract these works so long as credit is given. To copy in all other cases or to republish or to post on a server or to redis tribute to lists requires specific permission from the publisher at Publisher@InformingScience.org

\section{Distance Education Defined}

Distance education has been defined in a variety of ways. The Distance Education Clearinghouse offers several variants (http://www.uwex.edu/disted/definition.html). Distance education has generally bee $n$ seen as a means of instructional delivery that is not space- 


\section{Distance Education in Library and Information Science Discipline}

bound and sometimes not time-bound. It employs a range of technologies and with the advent of the Internet and more particularly the World Wide Web; it has come to often mean a system utilizing sophisticated electronic delivery methodologies. The United States Distance Learning Association defines it as:

Distance Education (Learning) - education program whereby students may complete all or part of an educational program in a geographical locatio $n$ apart from the institution hosting the program; the final award given is equivalent in standard and content to an award program completed on campus. (http://www.usdla.org/html/resources/dictionary.htm)

\section{Distance Education in Context}

James Taylor (n.d.) ar gues persuasively that we are now in the fifth generation of distance education. The fifth generation offers extensive technological and pedagogical resources to its students, teachers, and institutions. It is differentiated from earlier periods more by technological change as a means for delivery and access to resources rather than by a change in content or purpose.

Perhaps as a consequence of the potential reach of distance education and therefore the increased size of the potential market, there is now developing efforts to commercialize it on a scale heretofore not witnessed. Katz and Oblinger (2000), for example, document the comodification of "e-education." The advent of courseware is an example of commercial, private sector entry into course delivery. Many institutions, some long-established universities and other more recent entrepreneurial efforts have sought to capitalize on the explosion and popularity of distance programs. These range from relatively "simple" programs to teach specific skills (e.g. VideoProfessor's CD-ROM programs to teach computer software) to a variety of fult fledged undergraduate and graduate degree programs.

Distance education is a rapidly growing yet controversial experiment in higher education. Not only have individual colleges and universities sought to provide distance educations, several consortia have been developed to provide it perhaps in a more efficient way. The have included the Western Governors University (http://www.wgu.edu/wgu/about/), Universitas 21 (http://www.universitas.edu.au/), and the now defunct California Virtual U. As the California Virtual U experience illustrates, distance education, ho wever offered, does not carry a guarantee of success.

The African Virtual University (http://www.avu.org/) is another and somewhat different experiment in distance education. AVU joins universities in Sub-Saharan Africa with North American and European institutions to deliver instruction via a range of electronic media from one institution to others.

Charles Sturt University in New South Wales, Australia has entered into a cooperative agreement to offer distance instruction to students at the University of Mauritius and in Hong Kong. For More information on the Charles Sturt initiatives, see

http://www.csu.edu.au/handbook/handbook02/undergrad/u1216.htm and

http://www.csu.edu.au/faculty/sciagr/sis/admin/sishome.htm.

American library and information science programs have not jointly or individually participated in course exchanges or distance teaching across international lines, although this is beginning to change. Emporia State University's School of Library and Information Management's (SLIM) Nigeria Project (http://slim.emporia.edu/globenet/Nigeriaproject/index.htm) represents an agreement between SLIM and three Nigerian universities to among other things facilitate library education. Valdosta State University's Master of Library and Information Science Program has offered three of its on- line courses to Makerere University's East African School of Library and Information Science on CD-ROM. 


\section{Technology and Change}

For most of its history, correspondence distance education has relied on the postal service to deliver course materials from the teacher to the student and assignments from the student to the teacher. Technology has changed that. Today, courses are offered using a wide array of formats and technologies, including postal delivery. Some correspondence courses can and are offered over standard television. In the United States, high school equivalency course lectures are often offered in the early morning hours over public television. Many assignments are returned by mail and now by e- mail attachment.

Electronic technologies can be divided into two general groups: synchronous and asynchronous delivery methods. The traditional classroom setting, celebrated from Socrates seated under a tree interrogating a small group of acolytes to the very large lecture halls of today represent traditional synchronous course delivery: instructor and students together at the same time and in the same place hopefully to learn. Distance synchronous course delivery is also "live;" that is, both the student(s) and instructor(s) are connected by electronic means - perhaps two-way closed circuit television or through Internet carried H323 compliant linkages. Sometimes, synchronous courses are offered using television one-way and twoway telephone conferencing communication. The advantage of synchronous instruction is that it permits real-time interaction between student and instructor and among students. The impersonal nature of electronic communication, on the other hand, tends to the limit the social and often pedagogical value of that exchange.

Asynchronous technologies are teaching systems where the creation and delivery of instruction and the consumption of instruction occur at different times and usually in different places. Libraries might be thought of as vehicles for the delivery of asynchronous instruction (see e.g. Katz 2002: 8-13). Libraries acquire materials in print and "non-traditional" formats. These materials are consumed by library patrons, sometimes with the assistance of library staff and sometimes without that assistance. History is replete with anecdotes of the self-educated and successful individual. In the United States, we hold up Abraham Lincoln, the sixteenth President, as an example of a truly self-taught man.

The correspondence course, discussed above, is another example of asynchronous instruction. A number of American universities have built entire degree programs around synchronous instruction. Perhaps the best known of these is Phoenix University. Today electronic asynchronous instruction takes many forms with a number of variations. Courses can be placed on CD-ROM. They may be offered using various course-ware packages. Or they may be offered through a Web site. Courses, more particularly lectures are also offered on videotape or similar vehicle to be viewed in the classroom or in private, at a fixed time or at will during a defined period of time.

Nearly all North American schools of library and information science offer asynchronous and synchronous instruction using a variety of models. The following is a brief and non -exhaustive discussion of those models.

\section{Emporia State University, Kansas (http://slim.emporia.edu/text/deptext.htm)}

Emporia State University offers its distance program in seven states. The program utilizes asynchronous technologies but anticipates adoption and implementation of synchronous Webcasting.

Florida State University (http://www.lis.fsu.edu/)

Florida State University offers an asynchronous "distance" MS and an MA as well as a Specia 1ists degree using Web based technology. FSU offers some courses in both forma ts.

University of North Texas (http://www.unt.edu/slis/)

The University of North Texas offers a Web based Masters degree. The curriculum includes an eight or nine day that block of on site instruction and orientation. 


\section{Distance Education in Library and Information Science Discipline}

University of Oklahoma School of Library and Information Studies (http://www.ou.edu/cas/slis/)

The University of Oklahoma offers synchronous interactive video (H323 compatible) and asynchronous Web-based instruction for both its MLIS and Bachelors of Arts in Information Science programs. The School also offers a Web-based graduate level social science reference course to US military facilities in Asia, Europe, and the United States.

University of South CaroIna College of Library and Information Science (http://www.libsci.sc.edu/)

The University of South Carolina CLIS began its distance program in 1976 and migrated to televised education in 1982. It has since expanded televised delivery of instruction in West Virginia and Georgia. It has also provided cohort education to students in Maine through an agreement with the University of Maine. Both asynchronous and synchronous televised instruction, together with Internet based teaching and discussion methods are employed.

University of Tennessee School of Information Science (http://www.sis.utk.edu/)

The University of Tennessee offers annually a cohort class by distance education delivery. Students are required to attend an on-campus orientation program at the beginning of the program. Both synchronous and asynchronous Web-based course delivery is employed. Students must possess adequate computing capability to support required soft ware to support synchronous instruction.

\section{Valdosta State University, Georgia, Master of Library and Information Science Program}

The Valdosta State University (VSU) Master of Library and Information Science Program (MLIS) takes a several fold approach to distance education. It offers asynchronous courses through course-ware or as Web sites. The VSU Program recognizes that on- line courses developed and offered by other schools and organizations can provide curriculum building alternatives. The program has undertaken to incorporate a limited number of courses developed els ewhere into its curriculum.

This discussion illustrates the variety and adaptability of US programs to meet the distance needs of their students. As discussed above distance education is not a new concept. LIS programs have been offered overtime at satellite campuses and via the postal service. Radio, television, audio and video, CDROM, and now Internet technologies have been adopted and adapted to deliver some or all components of LIS degree programs by nearly all LIS programs in the United States. As new technologies become available, LIS programs have been early adaptors to find new and innovative ways to deliver instruction to distant audiences.

\section{DE and the Student}

Many educators recognize that distance education has its advantages and disadvantages (see Carswell and Venkatesh 2002; Schardt, Garrison, and Kochi 2002). Distance education, for all of its advantages, fails in one notable respect - it does not and cannot develop the range of networking that more traditional approaches can. Thus one drawback of distance education is the difficulty of building student to student or faculty to student interaction. Distance and relative anonymity create barriers for the development and growth of collegiality. The correspondence model particularly lends itself to that difficulty in part because instruction is almost always on a one-to-one basis and because the student and instructor may never make an effort to interrelate - and the course may be structured purposefully to promote a high degree of anonymity.

There has been much debate among LIS educators on its merits and demerits in the LIS environment. We must first recognize that the "typical" LIS student is an "atypical" graduate student in some respects. In the United States and unlike most of the rest of the world, LIS education is primarily conducted at the 
graduate level and this has been the norm for many decades (Koren 2002). American students come to the discipline with a minimum of a bachelor's degree in some other field and many hold higher degrees including the Ph.D., J.D., and M.B.A. They frequently come with significant work experience, sometimes with library or information credentials but often after careers in different fields. These stud ents are typically older than their graduate student peers in other fields and come to us with established families - that is, married with children. We conclude that these student are perhaps best equipped to function in a distance education environment, where the need to build initial social and career building networks is less important than once they were.

Students report a number of both positive and negative experiences with the many aspects of distance learning. Evidence suggests that students in distance courses tend to rate the course and the instructor lower than students in traditional face-to-face courses. While on the faculty of another library school, I conducted research on student responses to course evaluations. That institution offered synchronous "TV-based" simultaneous instruction at two or more sites, with the instructor lecturing "live" before a student audience at one of the sites. While the student groups at the various sites were not mirrors of one another - students at the "home' site tended to be younger, fulltime students while those at satellite sites were older, part time, working students - students at the home site usually ranked both the course and the instructor fully one point higher on average on a five point scale multi-question evaluation form. That said, students do recognize that if it were not for distance education, the likelihood that they could successfully complete graduate LIS education would be greatly diminished.

\section{US Higher Education Model}

In order to understand the place of distance education in context, a brief discussion of the US model is appropriate. In the United States there are both public and private colleges and universities. Public colleges and universities are supported primarily by government at the state and not the federal level. Students who are residents of the state in which the university they attend is located receive significant tuition benefits over students who are non-residents. Private colleges and universities almost without exception are far more expensive than are public schools, even for non-resident students. Tuition expenses are often mitigated in whole or in part through scholarships and fellowships at both public and private schools.

Postgraduate, that is, post-bachelors degree education can be divided into graduate and professional training. Professional education - medicine, law, business, and to some degree LIS - is usually not subsidized by scholarships or fellowships. Graduate education - the liberal arts and the more theoret ical aspects of the professions - on the other hand is usually supported through a number of mechanisms, including fellowships, scholarships, and graduate and teaching assistantships.

For the most part, masters level LIS students training for careers in librarianship do not receive significant tuition and living expense subsidy. It is therefore often in their financial best interest to attend the public professional school in their state of residence.

There are now emerging some significant exceptions to this tuition/residence rule. For example, in the southeastern part of the United States, a number of states have entered into an academic common market. Students resident in one state may attend a program in another state at "in-state" rates if there is not comparable program at a state school in their home state. Much benefit has gone to students seeking education in medicine, dentistry, veterinary medicine, and some aspects of business education. LIS students in Georgia have benefited from the program since until Valdosta State University began admitting students to its LIS program for the 2001-2002 academic year, there had never been a public state supported program in the state. Until 1991 Emory University did have a program and Clark Atlanta University has had an LIS program for many years, but both of these schools are private. 


\section{Distance Education in Library and Information Science Discipline}

Second, a number of schools that offer a fully articulated MLIS program on- line do not discriminate between in-state and out-of-state students for tuition. Both groups are charged at the in-state rate. It is argued that because neither group of students impact university infrastructure significantly and therefore do not make major use of state-funded resources, the reason for the distinction between in-state and outof- state students is reduced. Perhaps this is so, however the state nevertheless underwrites a significant portion of faculty and staff salaries and the use of university facilities, including the electronic use of university libraries.

\section{The Case Study}

Valdosta State University (VSU) inaugurated a new program in library and information science at the beginning of the 2001-2002 academic year. In developing the curriculum, the VSU MLIS program has followed a multi-faceted strategy. These include the development of Web-based asynchronous courses, traditional face-to-face instruction, and the use of hybrid courses. Hybrid courses are defined as those that incorporate both face-to-face seat time instruction and some form of distance education. In addition, the MLIS program has sought to leverage its course offerings by acquiring courses from other institutions or by cross- listing courses with other departments within the University or with other departments at other universities.

We have sought to employ innovative means to bring quality LIS education to our students. While Valdosta State University is conceived as a regional university to serve the southern tier of the state, the library program addresses a state-wide audience. From the beginning, the decision was taken to integrate both traditional face-to-face instruction with various approaches to distance learning. Therefore our curriculum is a combination of traditional, distance, and hybrid approaches.

Our faculty develop and deliver traditional and distance courses. For the distances courses, we employ asynchronous Web-based approaches. The state of Georgia has adopted one courseware as its standard, although other courseware packages are permitted. Our faculty have either developed their courses using the standard courseware or are migrating existing courses to the standard or they have developed their courses as html-based Websites. The latter approach forces the faculty member to do more "hands-on" Website development and "deprives" them of some of the courseware advantages. On the other hand, some feel that it allows greater control over instructional delivery.

We have also explored other approaches to course development. The include course acquisitions, course cross-listing, and cooperative inter-university programs. These strategies are discussed below:

\section{Course Acquisitions}

One of the "founding principles" of the VSU MLIS Program is a belief that efficiencies can be introduced into our curricula by acquiring asynchronous Web-based courses and course material from other LIS programs. As the program was originally designed, it was expected that VSU MLIS students might earn up to eighteen semester hours of credit from courses originating at LIS programs other than at VSU.

We recognize that there are two very different philosophies for acquisition of those courses. First VSU MLIS students could enroll in LIS courses at other institutions and transfer course credits back to VSU. There are two variants on this. Students could enroll in courses at other institutions "vetted by" and on the specific recommendation and approval of the VSU MLIS program. Or, they could shop those courses on their own.

Second, the VSU MLIS program could negotiate to acquire courses from other institutions and import those courses into the VSU MLIS curriculum. In so doing, those courses would be offered under a VSU course number. This would allow VSU to enroll in VSU courses and obviate the need to apply to and be accepted by some number of programs at other institutions. We believe there at least two variants for 
this model. First, the VSU MLIS program could contract with another program or another faculty member to offer course(s) and to take full responsibility for pedagogy, teaching, and student evaluation. This we might term "adjunct at a distance." One way to implement the model, in fact, would be to appoint the course owner/teacher to the adjunct faculty. Second, the VSU program could purchase course content much in the same way as one assigns textbooks written by others to one's students. All othe r responsibilities for course delivery, teaching, and student evaluation would the responsibility of a VSU faculty member.

\section{Course Cross-Listing}

The VSU MLIS Program seeks to leverage local University resources to increase electives offerings from our students. To date two courses have been approved: Information Management. This is a Public Administration course addressing "...issues and problems of information management..." of public organizations. We have also cross- listed a course with the History Department on the history of the book.

\section{Cooperative Inter-University Programs}

We are discussing a cooperative inter-university program with the Georgia College and State University, Milledgeville. GCSU offers an MA in History with an Archives Concentration. The degree program consists of two three-hour graduate courses (Archival History and Issues and Archival Methods and Practice) and a six-hour practicum. GCSU, like VSU is part of the University System of Georgia. We are now exploring ways to incorporate the archival concentration at GCSU into the VSU MLIS program as a concentration option.

Second, a jointly taught DE course in information ethics was offered jointly by VSU and Drexel University during the fall semester 2002 . The faculty member at each institution took responsibility for her/his students, but the courses were other integrated as fully as possible.

\section{Findings}

Our experience with distance education is a relatively short one. We agree with Salas et al (2002) who have observed that our theoretical understanding of distance education has lagged behind practice. Our observations contribute to the empirical and descriptive base from which theory might later be drawn. That said, however, we offer the following:

- Students consistently express a preference for face-to-face courses but nevertheless recognize that in the absence of distance education alternatives, the probability that they would or could attend class would be markedly diminished.

- Students tend to be more critical of on line course content and of their instructors than they are of face-to-face instruction.

- Students are more aware of and more likely to point out dated or erroneous material in Webbased courses than they are in face-to-face courses.

- Some courses are more amenable to distance delivery than are others. We have found that the teaching of specific skills is more difficult in an online environment than more theoretical material. For example, teaching software online has proven to be problematic and we have found it necessary to adopt a more hybrid approach.

- Both students and instructors find networking and "bonding" more difficult in an online environment, but virtual communities do sometimes emerge and persist. 


\section{Distance Education in Library and Information Science Discipline}

- Adoption of courses from or cooperation with other institutions carries many benefits, but there are also coordination and integration problems associated with the relationship. There are equally complex institutional and bureaucratic issues that inevitably arise.

- Technophobic responses from students and instructors are inevitable. Much care must be given to providing both with skills and support for online learning to be successful.

We are still struggling to understand the implications of the distance education explosion going on around us. Our experience tells us that our students prefer the intimacy of the classroom but they also understand the economics of distance education. For our students, intimacy yields to economics. We hope these observations help promote an understanding of the implications of the art into the future.

\section{References}

Carswell A. \& Venkatesh, V. (2002). Learner outcomes in an asynchronous distance education environment. International Journal of Human-Computer Studies 56 (5): 475-494.

Katz, R. \& Oblinger, D. eds., (2000). The "E" is for Everything: e-Commerce, e-Business and e-Learning in the Future of Higher Education. San Francisco: Jossey-Bass.

Katz, W. (2002). Introduction to Reference Work: Reference Services and References Processes. Vol 2. $8^{\text {th }}$ ed. Boston: McGraw Hill.

Koren, J. (2002). Bachelors and Spinsters or Masters and Mistresses? The Degree in the Glocal Portal. Sofia 2002 [Confe rence]: Libraries, Civil Society and Social Development. Sofia, Bulgaria, November 14-16, 2002. Forthcoming in Pro ceedings.

Salas E, Kosarzycki, M.,Burke,C., Fiore, S., \& Stone, D. (2002). Emerging themes in distance learning research and practice: some food for thought. International Journal of Management Reviews 4 (2): 135-153.

Schardt C., Garrison, J., \& Kochi, K. (2002). Distance education or classroom instruction for continuing education: who retains more knowledge? Journal of the Medical Library Association 90 (4): 455-457.

Sloan, B. \& Stoerger, S. (2002). Library Support for Distance Learning. Available: http://www.lis.uiuc.edu/ bsloan/libdist.htm

Taylor, J. (n.d., 2002?). Fifth Generation Distance Education. Available: http://www.icde.org/oslo/icde.nsf/print/FD5130FDCE096DA341256C3F00397748!OpenDocument 